\title{
Identification and proteolytic activity quantification of Pseudomonas spp. isolated from different raw milks at storage temperatures
}

\author{
Lu Meng, ${ }^{*} \dagger{ }^{1}$ Huimin Liu, ${ }^{*}{ }^{1}$ Lei Dong, ${ }^{*} \ddagger^{1}$ Nan Zheng, ${ }^{*} \dagger$ Mengru Xing, ${ }^{*} \ddagger$ Yangdong Zhang, ${ }^{*} \dagger$ \\ Shengguo Zhao, ${ }^{*} \dagger$ and Jiaqi Wang ${ }^{*} \dagger^{2}$ \\ *Ministry of Agriculture Laboratory of Quality and Safety Risk Assessment for Dairy Products, Institute of Animal Science, \\ Chinese Academy of Agricultural Sciences, Beijing 100193, China \\ †Ministry of Agriculture Milk and Dairy Product Inspection Center, Beijing 100193, China \\ ¥College of Food Science and Engineering, Qingdao Agricultural University, Qingdao 266109, China
}

\section{ABSTRACT}

Commercial milk products worldwide come not only from cows, but also from goats, buffaloes, camels, and yaks. Milk from non-bovine animals is important culturally and economically. Pseudomonas spp. are frequently linked to milk spoilage under storage temperatures. The objectives of this study were to identify Pseudomonas spp. isolated from goat, buffalo, camel, and yak milks, and to measure proteolytic activity of Pseudomonas spp. under different storage temperatures. Raw milk samples of goat $(\mathrm{n}=50)$, buffalo $(\mathrm{n}=25)$, camel $(\mathrm{n}=25)$, and yak $(\mathrm{n}=25)$ were collected from 5 provinces in China. Pseudomonas spp. were analyzed by Pseudomonas-specific $16 \mathrm{~S}$, universal $16 \mathrm{~S}$ rRNA, and rро $B$ gene sequence analyses. Proteolytic activity on milk agar, quantification via the trinitrobenzenesulfonic acid assay at $2^{\circ} \mathrm{C}, 4^{\circ} \mathrm{C}, 7^{\circ} \mathrm{C}, 10^{\circ} \mathrm{C}$ and $25^{\circ} \mathrm{C}$, as well as alkaline peptidase gene $(\operatorname{apr} X)$ identification were performed to ascertain the proteolytic activity of these isolates. Pseudomonas spp. were found in 46 samples out of total 125 samples. A total of 67 Pseudomonas spp. were identified. Of Pseudomonas isolates, we obtained extracellular peptidase activity in $7(10.4 \%)$ at $2^{\circ} \mathrm{C}, 17(25.4 \%)$ at $4^{\circ} \mathrm{C}, 24(35.8 \%)$ at $7^{\circ} \mathrm{C}, 39(58.2 \%)$ at $10^{\circ} \mathrm{C}$, and $41(61.2 \%)$ at $25^{\circ} \mathrm{C}$. The results revealed that a wide diversity of Pseudomonas spp. were present in different non-bovine raw milks, with the ability to produce peptidases at storage temperatures. However, proteolytic activity varied widely among the peptidasepositive isolates. A majority of isolates from yak milk had high proteolytic activity.

Key words: non-bovine raw milk, Pseudomonas spp., proteolytic activity, spoilage

Received July 31, 2017.

Accepted September 16, 2017.

${ }^{1}$ These 3 authors contributed equally.

${ }^{2}$ Corresponding author: jiaqiwang@vip.163.com

\section{INTRODUCTION}

The largest proportion of commercial milk products is derived from cows. However, milks from other ruminants (e.g., goats, buffalos, camels, and yaks) are also important culturally and economically (Quigley et al., 2013). Milk from different animals varies in its nutritional value, presence of bioactive vesicles, and potential therapeutic properties (Guo et al., 2014; Baddela et al., 2016; Kumar et al., 2016). The microbial populations of goat, buffalo, camel, and yak milk play significant roles in fermentation, milk spoilage, and health promotion (Quigley et al., 2013).

Psychrotrophic bacteria, which cause spoilage, have the ability to grow at refrigerated storage temperatures $\left(1^{\circ} \mathrm{C}\right.$ to $4^{\circ} \mathrm{C}$; Quigley et al., 2013; Li et al., 2016). Psychrotrophic microorganisms comprise the main microbial population in refrigerated raw milk (Xin et al., 2017). Among psychrotrophic microorganisms, Pseudomonas has been identified as the major genus in milk, leading to poor quality of raw milk (Marchand et al., 2009; Baur et al., 2015a; de Oliveira et al., 2015). Pseudomonas spp. produce several extracellular enzymes (e.g., peptidases and lipases). Although Pseudomonas bacteria are sensitive to pasteurization and UHT, their heat-stable enzymes could contribute to coagulation and reduced quality of milk and dairy products (Rajmohan et al., 2002; Dufour et al., 2008; Marchand et al., 2008).

Peptidases secreted by Pseudomonas spp. are primarily active on casein, leading to alterations in the physico-chemical and organoleptic properties of raw milk (Dufour et al., 2008). These peptidases belong mainly to the class of metallopeptidases (EC 3.4.24; Scatamburlo et al., 2015; Caldera et al., 2016). The heat-resistant peptidase alkaline metallopeptidase (AprX), which belongs to the serralysin family, is widespread among Pseudomonas spp. It is responsible for the spoilage of milk because of its high protein-degrading activity. The spoilage effects of Pseudomonas spp. vary dramatically 
Table 1. Primer sequences used in the study

\begin{tabular}{llll}
\hline Primer & Sequence $\left(5^{\prime}\right.$ to $\left.3^{\prime}\right)$ & Amplified region & Reference \\
\hline PA-GS-F & GACGGGTGAGTAATGCCTA & 16S gene signature for Pseudomonas & Spilker et al. (2004) \\
PA-GS-R & CACTGGTGTTCTTCCTATA & & 16S rRNA gene (universal primer) \\
$27 F$ & AGAGTTTGATCCTGGCTCAG & & Scarpellini et al. (2004) \\
$1492 R$ & CTACGGCTACCTTGTTACGA & rpoB & Decimo et al. (2014) \\
PSF & AGTTCATGGACCAGAACAACC & aprX gene of Pseudomonas & Sajben et al. (2011) \\
PTR & CCTTGACGGTGAACTCGTTTC & Caldera et al. (2016) \\
SM2F & AAATCGATAGCTTCAGCCAT & & \\
SM3R & TTGAGGTTGATCTTCTGGTT & & \\
\hline
\end{tabular}

depending on strains and growth conditions (Chessa et al., 2000; Chabeaud et al., 2001; Nicodème et al., 2005).

There are differences in nutrient composition and microbiota among milks; however, optimal storage conditions are similar for non-bovine and bovine raw milk. Therefore, the aims of this study were to (1) identify Pseudomonas spp. from goat, buffalo, camel, and yak milks obtained from 5 provinces in China; and (2) evaluate the proteolytic activity of these isolates. This study contributes to our understanding of the occurrence of the most important Pseudomonas species and their spoilage peptidase activity in goat, buffalo, camel, and yak raw milks.

\section{MATERIALS AND METHODS}

\section{Sample Collection and Pseudomonas spp. Identification}

We collected 125 raw milk samples from dairy herds in China, including 25 milk samples of goat from Shaanxi province (in spring), 25 milk samples of goat from Shandong province (in spring), 25 milk samples of buffalo from Guangxi Zhuang Autonomous Region (in spring), 25 milk samples of camel from Xinjiang Uygur Autonomous Region (in spring), and 25 milk samples of yak from Sichuan province (in summer). All samples were collected in bulk tanks, transferred into sterile plastic bottles (Corning Inc., Corning, NY), and transported to the laboratory at $4^{\circ} \mathrm{C}$ within $4 \mathrm{~h}$.

The isolation and identification of Pseudomonas spp. were performed as reported by Scatamburlo et al. (2015). Briefly, all raw milk samples were diluted 10 -fold in $0.85 \% \mathrm{NaCl}$ (wt/vol) and homogenized. Aliquots $(1 \mathrm{~mL})$ of selected dilutions were placed onto Pseudomonas agar (Oxoid Ltd., Basingstoke, UK), which is composed of $16.0 \mathrm{~g} / \mathrm{L}$ gelatin peptone, 10.0 $\mathrm{g} / \mathrm{L}$ casein hydrolysate, $10.0 \mathrm{~g} / \mathrm{L}$ potassium sulfate, 1.4 $\mathrm{g} / \mathrm{L}$ magnesium chloride, and $11.0 \mathrm{~g} / \mathrm{L}$ agar, and the $\mathrm{pH}$ was adjusted to $7.1 \pm 0.2$ at $25^{\circ} \mathrm{C}$. The Pseudomonas agar was supplemented with penicillin $(100,000$ IU/L, Dr. Ehrenstorfer GmbH, Augsburg, Germany) and pimaricin (0.01 g/L, Dr. Ehrenstorfer GmbH) to selectively isolate Pseudomonas spp. The plates were incubated at $25^{\circ} \mathrm{C}$ for $48 \mathrm{~h}$. Five to 8 colonies from each plate were streaked onto new Pseudomonas agar plates (Oxoid Ltd.) and incubated at $25^{\circ} \mathrm{C}$ for $48 \mathrm{~h}$.

Isolates of Pseudomonas spp. were identified by PCR thermal cyclers (Bio-Rad S1000; Bio-Rad, Hercules, $\mathrm{CA}$ ) and $16 \mathrm{~S}$ rRNA and rpoB sequencing. First, DNA of each isolate was extracted using the InstaGene Matrix DNA extraction kit (Bio-Rad) following the manufacturer's instructions. The PCR reaction mixtures (25 $\mu \mathrm{L})$ consisted of $12.5 \mu \mathrm{L}$ of EmeraldAmp Max PCR Master Mix (Takara, Dalian, China), 9.5 $\mu \mathrm{L}$ of deionized water (Takara), $1 \mu \mathrm{L}$ of each primer (100 $\mu M$; Sangon Biotech Shanghai Co. Ltd., Shanghai, China; Table 1 ), and approximately $50 \mathrm{ng}$ of bacterial genomic DNA. A negative control (a sample without genomic DNA) and a positive control (DNA of $P$. fluorescens CICC 21620; China Center of Industrial Culture Collection, Beijing, China) were included in all PCR assays.

We identified Pseudomonas spp. by evaluating a genus-specific region of $16 \mathrm{~S}$ rDNA. The amplification conditions consisted of 1 cycle at $95^{\circ} \mathrm{C}$ for $2 \mathrm{~min}$; followed by 25 cycles at $94^{\circ} \mathrm{C}$ for $20 \mathrm{~s}, 54^{\circ} \mathrm{C}$ for $20 \mathrm{~s}$, and $72^{\circ} \mathrm{C}$ for $40 \mathrm{~s}$; and a final extension step at $72^{\circ} \mathrm{C}$ for 1 min (Scatamburlo et al., 2015). Amplicons of 618 bp were considered indicative of Pseudomonas.

The 16S rRNA gene was then amplified under the following conditions, 1 cycle at $94^{\circ} \mathrm{C}$ for $4 \mathrm{~min} ; 30$ cycles at $94^{\circ} \mathrm{C}$ for $1 \mathrm{~min}, 57^{\circ} \mathrm{C}$ for $30 \mathrm{~s}$, and $72^{\circ} \mathrm{C}$ for $1.5 \mathrm{~min}$; and 1 cycle at $72^{\circ} \mathrm{C}$ for $10 \mathrm{~min}$. Because the 16S rRNA gene is known for its low resolution for discriminating species within Pseudomonas, comparison of partial $r p o B$ sequences was also performed as a basis for phylogenetic analyses (Ercolini et al., 2007; Decimo et al., 2014). The thermal program consisted of 1 cycle at $94^{\circ} \mathrm{C}$ for $3 \mathrm{~min} ; 30$ cycles at $94^{\circ} \mathrm{C}$ for $1 \mathrm{~min}, 58^{\circ} \mathrm{C}$ for 1 min, and $72^{\circ} \mathrm{C}$ for $1 \mathrm{~min}$; and 1 cycle at $72^{\circ} \mathrm{C}$ for $10 \mathrm{~min}$.

Finally, the derived amplicons were sequenced (Sangon Biotech). All available sequence data of Pseudomonas spp. were analyzed using BLAST against the National Center for Biotechnology Information data- 
base (https://blast.ncbi.nlm.nih.gov/Blast.cgi). For universal $16 \mathrm{~S}$ rRNA and rpoB, the degree of homology was $>98 \%$.

\section{Proteolytic Activity}

Aliquots $(100 \mu \mathrm{L})$ of selected dilutions were plated onto Pseudomonas agar (as described before) previously supplemented with UHT milk (10\%, vol/vol; Granarolo S.p.A., Bologna, Italy). The plates were incubated at $2^{\circ} \mathrm{C}, 4^{\circ} \mathrm{C}, 7^{\circ} \mathrm{C}, 10^{\circ} \mathrm{C}$, or $25^{\circ} \mathrm{C}$ for $7 \mathrm{~d}$ and observed daily. The presence of a proteolytic halo was considered a positive result (Scatamburlo et al., 2015).

\section{Quantification of Proteolytic Activity}

The quantification of proteolytic activity was performed as reported by Caldera et al. (2016), with slight modifications. Based on the proteolytic activity results obtained from milk agar, Pseudomonas isolates were incubated in $5 \mathrm{~mL}$ of UHT milk (Granarolo S.p.A.) at $2^{\circ} \mathrm{C}, 4^{\circ} \mathrm{C}, 7^{\circ} \mathrm{C}, 10^{\circ} \mathrm{C}$, or $25^{\circ} \mathrm{C}$ for $5 \mathrm{~d}$. The milks were subsequently centrifuged at $6,000 \times g$ at $4^{\circ} \mathrm{C}$ for $20 \mathrm{~min}$ (Hitachi CR22GIII, Hitachi, Japan). The supernatant was transferred into a new tube (Corning Inc.) with added bronopol (Beijing Chemical Factory, Beijing, China) and sodium azide (Beijing Chemical Factory) at final concentrations of $0.025 \%$ and $0.01 \%$, respectively, to prevent bacterial growth. The supernatant (1 $\mathrm{mL}$ ) was added to $9 \mathrm{~mL}$ of fresh UHT milk (Granarolo S.p.A.) and incubated at $37^{\circ} \mathrm{C}$ for $14 \mathrm{~d}$. The bacterial cell pellets were diluted and plated on agar plates to calculate bacterial count.

Afterward, we used the trinitrobenzenesulfonic acid (TNBS) method to quantify free $\alpha$-amino groups, which can indicate protein hydrolysis (Polychroniadou, 1988; Marchand et al., 2009). Released $\alpha$-amino groups were reacted with TNBS reagent (Sigma-Aldrich, Bornem, Belgium) at pH 9.2 in the dark for $100 \mathrm{~min}$, and the intensity of the yellow-orange color was measured at $420 \mathrm{~nm}$ (Varioskan Flash Multimode Reader, ThermoFisher Scientific, Waltham, MA). The levels of proteolytic enzymes in raw milk were determined from the absorption ratios. Bacterial strains were considered active when the value of the proteolytic activity was more than $2 \mu \mathrm{mol}$ of glycine equivalents per $\mathrm{mL}$. The standard curve was generated using glycine (SigmaAldrich).

\section{aprX Analysis}

The aprX gene of Pseudomonas isolates was amplified using the primers shown in Table 1 . The amplification program consisted of 1 cycle at $94^{\circ} \mathrm{C}$ for $3 \mathrm{~min} ; 30$ cycles at $95^{\circ} \mathrm{C}$ for $15 \mathrm{~s}, 60^{\circ} \mathrm{C}$ for $15 \mathrm{~s}$, and $72^{\circ} \mathrm{C}$ for $30 \mathrm{~s}$; and 1 cycle at $72^{\circ} \mathrm{C}$ for $8 \mathrm{~min}$. The PCR products were electrophoresed in a 1.5\% (wt/vol) agarose gel in $0.5 \times$ Tris-borate EDTA, stained with SYBR Safe DNA Gel Stain (ThermoFisher Scientific), and visualized using VersaDoc (Bio-Rad).

\section{RESULTS}

\section{Molecular Classification and Identification}

Identification was based on universal $16 \mathrm{~S}$ rRNA and $r p o B$ gene sequences. To minimize the chances of colonies being from the same strain, several colonies of different morphologies were selected from each sample. Pseudomonas spp. were found in 46 samples of 125 samples originating from 125 separate dairy farms; 67 colonies were identified as Pseudomonas spp. (Tables 2, $3,4$, and 5$)$.

Species allocation was based on the 16S rRNA gene sequences and phylogenetic clustering of rpo $B$ gene sequence data. Several isolates were close to a particular species because they clustered together with a type strain $(\sim 99 \%)$. We did not obtain any rpoB sequences for 6 strains. Therefore, these strains were referred to as Pseudomonas sp. and named as Pseudomonas sp. 1 to 6 (Tables $2-5$ and Supplementary Table S1; https:// doi.org/10.3168/jds.2017-13617).

Ten goat milk isolates were identified as P. fluorescens and 7 were $P$. putida, respectively. The remaining 14 goat milk isolates belonged to $P$. fragi, $P$. moraviensis, P. cedrina, P. rhodesiae, P. protegens, P. lurida, $P$. reactans, $P$. chlororaphis, and $P$. poae. The 8 buffalo milk isolates were equally distributed among $P$. graminis, P. koreensis, and P. fluorescens. Six of 9 isolates from camel milk were identified as $P$. fluorescens and P. putida. In yak milk, P. fluorescens was the dominant species (31.6\% of 19 isolates), followed by undefined Pseudomonas sp. (26.3\%), P. fragi (15.8\%), and other strains (e.g., P. putida, P. veronii, P. reinekei, P. cedrina, and P. koreensis).

\section{Proteolytic Activity of the Isolates}

Tables 2 to 5 show the detailed phenotypic results. All 67 isolates grew between $4^{\circ} \mathrm{C}$ and $25^{\circ} \mathrm{C}$; however, 2 isolates did not grow at $2^{\circ} \mathrm{C}$. We obtained proteolytic activity in all isolates at all test temperatures (Table 6). Approximately $60 \%$ (39/67 and 41/67, respectively) of the isolates had extracellular peptidase activity on milk agar at $10^{\circ} \mathrm{C}$ and $25^{\circ} \mathrm{C}$ after $7 \mathrm{~d}$ of incubation. Approximately $30 \%(17 / 67$ and $24 / 67$, respectively) of the isolates had extracellular peptidase activity at $4{ }^{\circ} \mathrm{C}$ and $7^{\circ} \mathrm{C}$. At $2^{\circ} \mathrm{C}, 7$ isolates showed extracellular peptidase 
Table 2. The putative identification and phenotypical spoilage characterization of tested isolates (goat milk) from Shandong and Shaanxi provinces

\begin{tabular}{|c|c|c|c|c|c|c|c|c|c|c|}
\hline Isolate identification & \multicolumn{5}{|c|}{ Growth } & \multicolumn{5}{|c|}{ Extracellular peptidase activity on milk agar ${ }^{1}$} \\
\hline Pseudomonas putida & + & + & + & + & + & - & - & - & - & - \\
\hline Pseudomonas fluorescens & + & + & + & + & + & - & $+(4)$ & $+(4)$ & $+(3)$ & $+(1)$ \\
\hline Pseudomonas fluorescens & + & + & + & + & + & - & - & $+(7)$ & $+(3)$ & - \\
\hline Pseudomonas fragi & + & + & + & + & + & - & - & $+(5)$ & $+(3)$ & $+(3)$ \\
\hline Pseudomonas putida & + & + & + & + & + & - & - & - & - & - \\
\hline Pseudomonas putida & + & + & + & + & + & - & - & - & - & - \\
\hline Pseudomonas cedrina & + & + & + & + & + & - & - & $+(5)$ & $+(4)$ & $+(5)$ \\
\hline Pseudomonas putida & - & + & + & + & + & - & - & - & $+(5)$ & $+(5)$ \\
\hline Pseudomonas sp. 1 & + & + & + & + & + & - & - & - & - & $+(1)$ \\
\hline Pseudomonas fluorescens & + & + & + & + & + & - & - & - & $+(3)$ & $+(3)$ \\
\hline \multicolumn{11}{|l|}{ From Shaanxi province } \\
\hline Pseudomonas fragi & + & + & + & + & + & - & - & - & - & - \\
\hline Pseudomonas fragi & + & + & + & + & + & - & - & - & - & - \\
\hline Pseudomonas fluorescens & + & + & + & + & + & - & - & - & - & - \\
\hline Pseudomonas putida & + & + & + & + & + & - & - & - & - & $+(1)$ \\
\hline Pseudomonas protegens & + & + & + & + & + & - & - & - & $+(3)$ & $+(3)$ \\
\hline Pseudomonas fluorescens & + & + & + & + & + & - & - & - & $+(5)$ & $+(5)$ \\
\hline Pseudomonas fluorescens & + & + & + & + & + & - & - & - & - & $+(1)$ \\
\hline Pseudomonas fragi & + & + & + & + & + & - & - & - & - & - \\
\hline Pseudomonas lurida & + & + & + & + & + & - & $+(3)$ & $+(3)$ & $+(3)$ & $+(2)$ \\
\hline Pseudomonas reactans & + & + & + & + & + & - & - & $+(6)$ & $+(6)$ & $+(5)$ \\
\hline Pseudomonas chlororaphis & - & + & + & + & + & - & - & - & $+(4)$ & $+(5)$ \\
\hline Pseudomonas fluorescens & + & + & + & + & + & - & - & - & - & - \\
\hline Pseudomonas fluorescens & + & + & + & + & + & - & - & - & $+(5)$ & $+(5)$ \\
\hline Pseudomonas poae & + & + & + & + & + & $+(6)$ & $+(5)$ & $+(3)$ & $+(2)$ & $+(1)$ \\
\hline
\end{tabular}

${ }^{1}$ Numbers in parentheses indicate the incubation days required to observe proteolytic activities.

activity, and 4 of 7 isolates had peptidase activity after 6 and $7 \mathrm{~d}$ of incubation. No extracellular peptidase activity was observed on the first day between $2^{\circ} \mathrm{C}$ and $10^{\circ} \mathrm{C}$.

When focusing on isolates from different matrices (milk types), we observed several matrix-dependent findings. Extracellular peptidase activity at $25^{\circ} \mathrm{C}$ was observed in $75.0 \%(6 / 8)$ of buffalo milk isolates, $67.7 \%$ $(21 / 31)$ of goat milk isolates, $57.9 \%(11 / 19)$ of yak milk isolates, and $33.3 \%(3 / 9)$ of camel milk isolates. Similar results were obtained at $7^{\circ} \mathrm{C}$ and $10^{\circ} \mathrm{C}$. At $4^{\circ} \mathrm{C}$, we observed extracellular peptidase activity in $37.5 \%$ (3/8) of buffalo milk isolates, $26.3 \%$ (4/19) of yak milk isolates, $22.6 \%(7 / 31)$ of goat milk isolates, and $22.2 \%$

Table 3. The putative identification and phenotypical spoilage characterization of tested buffalo milk isolates from Guangxi

\begin{tabular}{|c|c|c|c|c|c|c|c|c|c|c|}
\hline \multirow[b]{2}{*}{ Isolate identification } & \multicolumn{5}{|c|}{ Growth } & \multicolumn{5}{|c|}{ Extracellular peptidase activity on milk agar ${ }^{1}$} \\
\hline & $2^{\circ} \mathrm{C}$ & $4^{\circ} \mathrm{C}$ & $7^{\circ} \mathrm{C}$ & $10^{\circ} \mathrm{C}$ & $25^{\circ} \mathrm{C}$ & $2^{\circ} \mathrm{C}$ & $4^{\circ} \mathrm{C}$ & $7^{\circ} \mathrm{C}$ & $10^{\circ} \mathrm{C}$ & $25^{\circ} \mathrm{C}$ \\
\hline Pseudomonas graminis & + & + & + & + & + & - & - & - & - & $+(5)$ \\
\hline Pseudomonas koreensis & + & + & + & + & + & - & $+(7)$ & $+(4)$ & $+(2)$ & $+(1)$ \\
\hline Pseudomonas fluorescens & + & + & + & + & + & - & - & - & $+(2)$ & $+(1)$ \\
\hline Pseudomonas graminis & + & + & + & + & + & - & - & - & - & - \\
\hline Pseudomonas koreensis & + & + & + & + & + & - & - & $+(4)$ & $+(3)$ & $+(1)$ \\
\hline Pseudomonas graminis & + & + & + & + & + & - & - & - & - & - \\
\hline Pseudomonas fragi & + & + & + & + & + & $+(5)$ & $+(2)$ & $+(2)$ & $+(2)$ & $+(1)$ \\
\hline Pseudomonas fluorescens & + & + & + & + & + & - & $+(7)$ & $+(6)$ & $+(3)$ & $+(1)$ \\
\hline
\end{tabular}

${ }^{1}$ Numbers in parentheses indicate the incubation days required to observe proteolytic activities. 
Table 4. The putative identification and phenotypical spoilage characterization of tested camel milk isolates from Xinjiang

\begin{tabular}{|c|c|c|c|c|c|c|c|c|c|c|}
\hline Isolate identification & \multicolumn{5}{|c|}{ Growth } & \multicolumn{5}{|c|}{ Extracellular peptidase activity on milk agar ${ }^{1}$} \\
\hline Pseudomonas putida & + & + & + & + & + & - & - & - & - & - \\
\hline Pseudomonas fluorescens & + & + & + & + & + & - & $+(4)$ & $+(3)$ & $+(3)$ & $+(1)$ \\
\hline Pseudomonas psychrophila & + & + & + & + & + & - & - & - & - & - \\
\hline Pseudomonas fragi & + & + & + & + & + & - & - & - & $+(3)$ & - \\
\hline Pseudomonas fragi & + & + & + & + & + & - & - & - & - & - \\
\hline Pseudomonas putida & + & + & + & + & + & - & - & - & - & - \\
\hline
\end{tabular}

${ }^{1}$ Numbers in parentheses indicate the incubation days required to observe proteolytic activities.

$(2 / 9)$ camel milk isolates. However, camel milk isolates had no peptidase activity at $2^{\circ} \mathrm{C}$. Therefore, buffalo milk had the most isolates with peptidase activity on milk agar at different storage temperatures, followed by isolates from goat milk and yak milk. Few isolates from camel milk had extracellular peptidase activity.

\section{Quantification of Proteolytic Activity}

We quantified the total proteolytic activity of all isolates in UHT milk (Figure 1). The strains were considered to have proteolytic activity when proteolytic activity was $>2 \mu \mathrm{mol}$ of glycine equivalent per $\mathrm{mL}$. The highest percentage of proteolytic activity isolates was obtained at $25^{\circ} \mathrm{C}(56.7 \%, \mathrm{n}=38)$ and $10^{\circ} \mathrm{C}(53.7 \%, \mathrm{n}=$ 36). At $7^{\circ} \mathrm{C}, 4^{\circ} \mathrm{C}$, and $2^{\circ} \mathrm{C}$, the percentage of proteolytic activity isolates was $23.9 \%(\mathrm{n}=16), 14.9 \%(\mathrm{n}=10)$, and $3.0 \%(\mathrm{n}=2)$, respectively.
Among the isolates from each milk matrix, different levels of proteolytic activity were detected, which could be attributed to different behavior of the isolated species. The isolates from yak milk had high activities, as did isolates from goat and camel milks.

\section{Analysis of aprX}

We amplified the apr $X$ gene from all isolates via PCR. An amplicon of the expected size $( \pm 850 \mathrm{bp})$ was obtained from 47 isolates. No amplification product was obtained in the remaining 20 isolates.

\section{DISCUSSION}

Psychrotrophs play a major role in the spoilage of refrigerated milk and milk products. Therefore, it is important to learn about the psychrotrophic bacteria

Table 5. The putative identification and phenotypical spoilage characterization of tested yak milk isolates from Sichuan province

\begin{tabular}{|c|c|c|c|c|c|c|c|c|c|c|}
\hline \multirow[b]{2}{*}{ Isolate identification } & \multicolumn{5}{|c|}{ Growth } & \multicolumn{5}{|c|}{ Extracellular peptidase activity on milk agar ${ }^{1}$} \\
\hline & $2^{\circ} \mathrm{C}$ & $4^{\circ} \mathrm{C}$ & $7^{\circ} \mathrm{C}$ & $10^{\circ} \mathrm{C}$ & $25^{\circ} \mathrm{C}$ & $2^{\circ} \mathrm{C}$ & $4^{\circ} \mathrm{C}$ & $7^{\circ} \mathrm{C}$ & $10^{\circ} \mathrm{C}$ & $25^{\circ} \mathrm{C}$ \\
\hline Pseudomonas putida & + & + & + & + & + & - & - & - & - & - \\
\hline Pseudomonas fragi & + & + & + & + & + & - & - & - & - & - \\
\hline Pseudomonas sp. 2 & + & + & + & + & + & - & - & - & - & - \\
\hline Pseudomonas sp. 3 & + & + & + & + & + & - & - & - & - & - \\
\hline Pseudomonas sp. 4 & + & + & + & + & + & - & - & - & - & - \\
\hline Pseudomonas sp. 5 & + & + & + & + & + & $+(5)$ & $+(4)$ & $+(2)$ & $+(2)$ & $+(1)$ \\
\hline Pseudomonas veronii & + & + & + & + & + & - & - & - & $+(4)$ & $+(6)$ \\
\hline Pseudomonas fluorescens & + & + & + & + & + & - & - & - & - & - \\
\hline Pseudomonas fluorescens & + & + & + & + & + & - & - & - & - & - \\
\hline Pseudomonas reinekei & + & + & + & + & + & $+(7)$ & $+(4)$ & $+(3)$ & $+(3)$ & $+(1)$ \\
\hline Pseudomonas fluorescens & + & + & + & + & + & - & - & - & $+(4)$ & $+(2)$ \\
\hline Pseudomonas cedrina & + & + & + & + & + & $+(7)$ & $+(7)$ & $+(4)$ & $+(6)$ & $+(3)$ \\
\hline Pseudomonas fragi & + & + & + & + & + & - & - & - & $+(4)$ & $+(3)$ \\
\hline Pseudomonas fluorescens & + & + & + & + & + & - & $+(4)$ & $+(4)$ & $+(2)$ & $+(1)$ \\
\hline Pseudomonas fragi & + & + & + & + & + & - & - & - & $+(3)$ & $+(2)$ \\
\hline Pseudomonas fluorescens & + & + & + & + & + & - & - & - & $+(4)$ & $+(3)$ \\
\hline Pseudomonas fluorescens & + & + & + & + & + & $+(6)$ & $+(3)$ & $+(3)$ & $+(2)$ & $+(2)$ \\
\hline Pseudomonas koreensis & + & + & + & + & + & - & - & $+(5)$ & $+(3)$ & $+(2)$ \\
\hline Pseudomonas sp. 6 & + & + & + & + & + & - & - & - & - & - \\
\hline
\end{tabular}

${ }^{1}$ Numbers in parentheses indicate the incubation days required to observe proteolytic activities. 
Table 6. Pseudomonas spp. isolates ${ }^{1}$ with observed proteolytic activity $^{2}$ at different temperatures

\begin{tabular}{lccccc}
\hline & \multicolumn{5}{c}{ Incubation temperature } \\
\cline { 2 - 6 } Day & $2^{\circ} \mathrm{C}$ & $4^{\circ} \mathrm{C}$ & $7^{\circ} \mathrm{C}$ & $10^{\circ} \mathrm{C}$ & $25^{\circ} \mathrm{C}$ \\
\hline 1 & 0 & 0 & 0 & 0 & 19 \\
2 & 0 & 2 & 3 & 10 & 7 \\
3 & 0 & 2 & 5 & 16 & 7 \\
4 & 1 & 6 & 8 & 8 & 0 \\
5 & 2 & 2 & 5 & 3 & 7 \\
6 & 2 & 0 & 2 & 2 & 1 \\
7 & 2 & 5 & 1 & 0 & 0 \\
Total & 7 & 17 & 24 & 39 & 41 \\
\hline
\end{tabular}

${ }^{1}$ The total number of Pseudomonas spp. isolates obtained from raw milk was 67 .

${ }^{2}$ As determined during growth on milk agar. The number of new isolates exhibiting extracellular proteolytic activity on a given day of incubation on milk agar is shown. present in bovine and non-bovine raw milks. In this study, we isolated Pseudomonas spp. in goat, buffalo, camel, and yak milks from 5 provinces; identified bacterial isolates to the species level; evaluated the proteolytic activity of Pseudomonas spp., and analyzed the presence of $\operatorname{apr} X$ as an indicator of proteolysis.

Following genomic confirmation of the genus level, the isolates were assigned at the species level. The identification of isolates was primarily based on $16 \mathrm{~S}$ rRNA and rpoB sequences. In general, we obtained a large diversity of Pseudomonas species in the raw milk samples from different sources. Pseudomonas fluorescens was the predominant strain in goat milk, and it has been recognized as an important agent of raw goat milk spoilage. Scatamburlo et al. (2015) identified 82 Pseudomonas isolates clustered into 5 groups from 61 raw goat samples; $50 \%(\mathrm{n}=42)$ of the isolates were identified as P. fluorescens, consistent with our results (Table 2). More Pseudomonas isolates were obtained
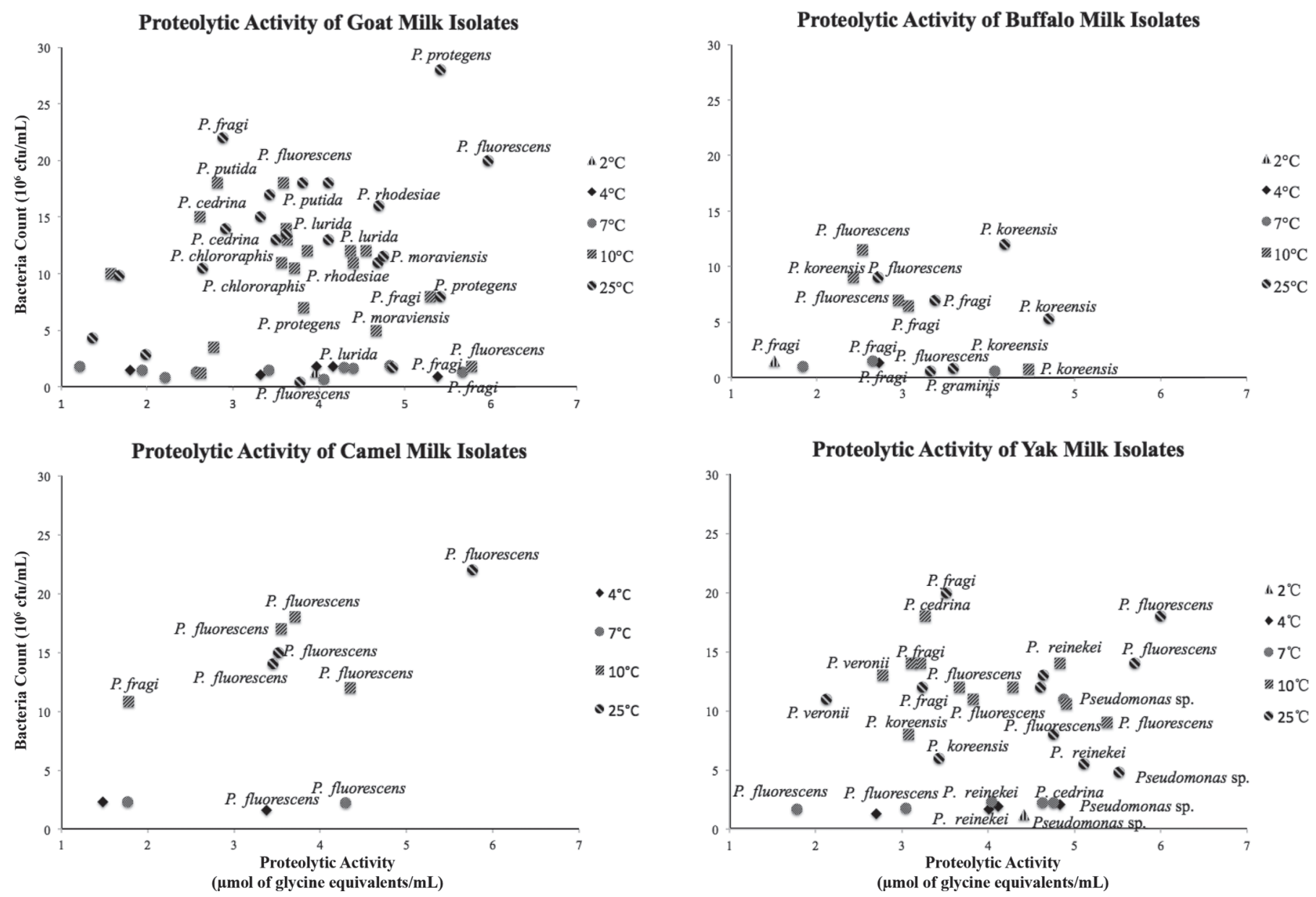

Figure 1. Proteolytic activity quantification of isolates obtained from goat, buffalo, camel, and yak milk samples stored for $5 \mathrm{~d}$ at $2^{\circ} \mathrm{C}, 4^{\circ} \mathrm{C}$, $7^{\circ} \mathrm{C}, 10^{\circ} \mathrm{C}$, or $25^{\circ} \mathrm{C}$. The x-axis represents proteolytic activity ( $\mu \mathrm{mol}$ of glycine equivalents per $\mathrm{mL}$ ), and the y-axis represents bacterial count $\left(10^{6}\right.$ $\mathrm{cfu} / \mathrm{mL}$ ). The species names of isolates with very low or no activity are not shown. 
from Shaanxi province than from Shandong province, reflecting a different farm environment. Raw buffalo milk contains a diverse microbial population. At the genus level, Streptococcus (14.2\%), Lactococcus (8.2\%), and Pseudomonas (4.9\%) were the 3 dominant populations in raw buffalo milk after $2 \mathrm{~h}$ of storage. After 72 $\mathrm{h}$ of storage, Pseudomonas was the dominant genus, accounting for more than $51 \%$ of total bacteria (Li et al., 2016). However, we identified 8 Pseudomonas isolates from 25 raw buffalo milk samples, which indicates that Pseudomonas spp. comprise a small proportion of the microflora buffalo when grazing, in the parlor, or during the milking process (Table 3 ).

Several peptidase-producing psychrotrophic bacteria can be isolated from raw camel milk. Zahran and AlSaleh (1997) identified Pseudomonas as the predominant peptidase-producing psychrotrophic bacteria in raw camel milk. However, among 25 raw camel milk samples, we obtained only 9 Pseudomonas isolates (Table 4). Among these 9 Pseudomonas isolates, P. fluorescens and P. putida were predominant. Similar results were reported by Zahran and Al-Saleh (1997).

Yak is an animal that is typically associated with difficult climates, and approximately $92 \%$ of the world yak population is located in China. Yak milk is produced during the summer. Most studies have focused on the presence of lactic acid bacteria, yeast, and coliforms in yak milk (Watanabe et al., 2008; Zhang et al., 2008; Yu et al., 2011). Our findings revealed that Pseudomonas spp. represent an important bacteria component of raw yak milk. More than 7 Pseudomonas spp. were identified in this study (Table 5), indicating a large diversity of Pseudomonas spp. in yak milk. Moreover, the count of isolated Pseudomonas strains was higher in yak milk $(\mathrm{n}=19)$ than in buffalo $(\mathrm{n}=8)$ or camel milk $(\mathrm{n}=$ 9 ), which may be due to the collection of yak milk in summer. Even though the biochemical and organoleptic characteristics of raw milk in different animal species differ widely, our findings indicate that Pseudomonas spp. are ubiquitous in milk.

The results showed that most isolates could grow at storage temperatures, except for 2 isolates from goat milk that were inhibited at $2^{\circ} \mathrm{C}$ (Tables $2-5$ ). MunschAlatossava and Alatossava (2006) reported that Pseudomonas strains isolated from farms failed to grow at $4^{\circ} \mathrm{C}$ or $7^{\circ} \mathrm{C}$, which suggests that the growth of Pseudomonas isolates is temperature-dependent (Willocx et al., 1993; Munsch-Alatossava and Alatossava, 2006).

Several Pseudomonas species produce extracellular peptidases that can affect different kinds of milk. At $10^{\circ} \mathrm{C}$ and $25^{\circ} \mathrm{C}$, most goat milk isolates $(\geq 60 \%)$ in the current study exhibited proteolytic activity, which is an important spoilage feature (Scatamburlo et al., 2015). As temperatures decreased from $7^{\circ} \mathrm{C}$ to $2^{\circ} \mathrm{C}$, less than
$40 \%$ of isolates from goat milk exhibited proteolytic activity. Although buffalo milk had the lowest number of strains, more than half of the isolates were proteolytically active at $7^{\circ} \mathrm{C}, 10^{\circ} \mathrm{C}$, and $25^{\circ} \mathrm{C}$. These results are consistent with the findings of Caldera et al. (2015), who reported that comparable levels of blue spoilage in mozzarella cheese were observed after $2 \mathrm{~d}$ at $25^{\circ} \mathrm{C}, 7$ d at $12^{\circ} \mathrm{C}$, and $17 \mathrm{~d}$ at $4^{\circ} \mathrm{C}$, respectively. However, the association between storage temperature and storage time for other milks, including camel milk, is unclear; in camel milk, a minor fraction of the isolates $(\leq 45 \%$ from $2^{\circ} \mathrm{C}$ to $25^{\circ} \mathrm{C}$ ) exhibited proteolytic activity. Fewer studies have been performed on yak milk, but the findings obtained here for extracellular peptidase activity were in agreement with those of cow milk (Wiedmann et al., 2000). Detectable extracellular peptidase activity is very important for assessing dairy product quality. Proteolytic enzymes degrade milk proteins, leading to the production of noxious end products and significant economic losses for the food industry (Dogan and Boor, 2003; Arslan et al., 2011).

Proteolytic activity was confirmed by quantitative analysis and reported as glycine equivalents per milliliter. Certain types of cheeses are produced using raw milk not subjected to any heat-processing conditions. Therefore, we quantified the native proteolytic activity, not just heat-resistant proteolytic activity. Goat and yak milk isolates had higher peptidase activity than buffalo and camel milk isolates at $2^{\circ} \mathrm{C}, 4^{\circ} \mathrm{C}$ and $7^{\circ} \mathrm{C}$. However, we obtained more isolates with peptidase activity from buffalo milk than from goat or yak milk at $10^{\circ} \mathrm{C}$ and $25^{\circ} \mathrm{C}$. A small percentage of camel milk isolates showed proteolytic activity. This is similar to the study of Glück et al. (2016), who evaluated the thermostability of peptidases from 231 microorganisms isolated from raw milk and reported that only 38 Pseudomonas isolates showed proteolytic activity after cultivation at $6^{\circ} \mathrm{C}$. In the study of Caldera et al. (2016), 33\% (3/9) of raw cow milk and pasteurized milk isolates and 52\% (12/23) of milk product (soft cheese and mozzarella) isolates had measurable proteolytic activity. Because our milk samples were from raw milk of different animal species and theirs were mainly from produced products, it is difficult to compare the results. However, Marchand et al. (2017) concluded that good quality cow milk (raw or processed) should have a mean TNBS value of approximately $1.01 \pm 0.04 \mu \mathrm{mol}$ of glycine equivalents per $\mathrm{mL}$. Also, they concluded that there was no clear correlation between the onset of off-flavors and the rate of protein hydrolysis in UHT-processed milk by different Pseudomonas peptidase groups.

Among the isolated species, we detected key differences in proteolytic activity. The highest proteolytic activity was detected in $P$. fluorescens in yak and camel 
milk. However, the proteolytic activity of all P. fluorescens varied considerably. We observed a large heterogeneity of $P$. fragi proteolytic activity, in agreement with the results reported by Caldera et al. (2016).

According to laws and local standards, raw goat milk, buffalo milk, and yak milk should be stored below $7^{\circ} \mathrm{C}$ (China Dairy Industry Association, 2012; The Guangxi Zhuang Autonomous Region Health and Family Planning Commission, 2014; Scatamburlo et al., 2015). Many studies have found that Pseudomonas spp. from cow milk produce peptidases at $4^{\circ} \mathrm{C}$ and $7^{\circ} \mathrm{C}$. In this study, we identified several Pseudomonas isolates from non-bovine milk that produced peptidases at different storage temperatures. This contributes to a very complex microbial ecology of raw milk, especially goat and yak milks, and creates challenges in the prevention of milk spoilage (Ercolini et al., 2009). Moreover, Baur et al. (2015b) and Glück et al. (2016) found that several peptidases secreted from Pseudomonas spp. withstood UHT treatments in milk and showed considerable proteolytic activity under storage conditions of UHT milk. Therefore, the storage temperatures for raw milk from goat and yak should be lower and storage time should be limited to a short period.

The match between the presence of apr $X$ and proteolytic activity on milk agar was convincing, confirming the role of AprX in milk degradation (Dufour et al., 2008; Caldera et al., 2016). However, 3 apr X-positive isolates did not exhibit proteolytic activity at any storage temperature, which indicated that AprX was not active during growth. In Pseudomonas, AprX is usually involved in nutrient utilization and extracellular protein degradation, resulting in it being an important bacterium in the spoilage of milk and dairy products (Zhang et al., 2009). Therefore, production of AprX highlights the importance of controlling Pseudomonas contamination by potentially using this enzyme as a key indicator of proteolysis.

In conclusion, our findings demonstrate that different raw milk types harbor a wide diversity of Pseudomonas spp. Most isolates are able to grow at storage temperatures and produce peptidases that affect milk quality. Our results highlighted the importance of Pseudomonas species as broadly adaptable spoilage organisms, of which P. fluorescens is the most common. Therefore, to control Pseudomonas spp. growth and prevent milk spoilage during the storage and transportation, correct storage temperatures and time should be established for raw milks originated from different animal species.

\section{ACKNOWLEDGMENTS}

This research was financially supported by the Project of Risk Assessment on Raw Milk (Beijing, China;
GJFP2016008), the Fundamental Research Funds for the Central Non-profit Research Institution (Beijing, China; 2015ywf-zd-3), the Special Fund for Agro-scientific Research in the Public Interest (Beijing, China; 201403071), the Agricultural Science and Technology Innovation Program (Beijing, China; ASTIP-IAS12), and the Modern Agro-Industry Technology Research System of the PR China (Beijing, China; CARS-37).

\section{REFERENCES}

Arslan, S., A. Eyi, and F. Özdemir. 2011. Spoilage potentials and antimicrobial resistance of Pseudomonas spp. isolated from cheeses. J. Dairy Sci. 94:5851-5856.

Baddela, V. S., V. Nayan, P. Rani, S. K. Onteru, and D. Singh. 2016 Physicochemical biomolecular insights into buffalo milk-derived nanovesicles. Appl. Biochem. Biotechnol. 178:544-557.

Baur, C., M. Krewinkel, B. Kranz, M. von Neubeck, M. Wenning, S. Scherer, M. Stoeckel, J. Hinrichs, T. Stressler, and L. Fischer. 2015a. Quantification of the proteolytic and lipolytic activity of microorganisms isolated from raw milk. Int. Dairy J. 49:23-29.

Baur, C., M. Krewinkel, I. Kutzli, B. Kranz, M. von Neubeck, C. Huptas, M. Wenning, S. Scherer, M. Stoeckel, J. Hinrichs, T. Stressler, and L. Fischer. 2015b. Isolation and characterisation of a heat-resistant peptidase from Pseudomonas panacis withstanding general UHT processes. Int. Dairy J. 49:46-55.

Caldera, L., S. Arioli, M. Stuknyte, M. Scarpellini, and L. Franzetti. 2015. Setup of a rapid method to distinguish among dead, alive, and viable but not cultivable cells of Pseudomonas spp. in mozzarella cheese. J. Dairy Sci. 98:8368-8374.

Caldera, L., L. Franzetti, E. Van Coillie, P. De Vos, P. Stragier, J. De Block, and M. Heyndrickx. 2016. Identification, enzymatic spoilage characterization and proteolytic activity quantification of Pseudomonas spp. isolated from different foods. Food Microbiol. 54:142-153.

Chabeaud, P., A. de Groot, W. Bitter, J. Tommassen, T. Heulin, and W. Achouak. 2001. Phase-variable expression of an operon encoding extracellular alkaline protease, a serine protease homolog, and lipase in Pseudomonas brassicacearum. J. Bacteriol. 183:2117-2120.

Chessa, J. P., I. Petrescu, M. Bentahir, J. Van Beeumen, and C. Gerday. 2000. Purification, physico-chemical characterization and sequence of a heat labile alkaline metalloprotease isolated from a psychrophilic Pseudomonas species. Biochim. Biophys. Acta 1479:265-274.

China Dairy Industry Association. 2012. China Dairy Industry Standard Raw Yak Milk. China Dairy Industry Association, Beijing, China.

de Oliveira, G. B., L. Favarin, R. H. Luchese, and D. McIntosh. 2015. Psychrotrophic bacteria in milk: How much do we really know? Braz. J. Microbiol. 46:313-321.

Decimo, M., S. Morandi, T. Silvetti, and M. Brasca. 2014. Characterization of Gram-negative psychrotrophic bacteria isolated from Italian bulk tank milk. J. Food Sci. 79:M2081-M2090.

Dogan, B., and K. J. Boor. 2003. Genetic diversity and spoilage potentials among Pseudomonas spp. isolated from fluid milk products and dairy processing plants. Appl. Environ. Microbiol. 69:130-138.

Dufour, D., M. Nicodeme, C. Perrin, A. Driou, E. Brusseaux, G. Humbert, J. L. Gaillard, and A. Dary. 2008. Molecular typing of industrial strains of Pseudomonas spp. isolated from milk and genetical and biochemical characterization of an extracellular protease produced by one of them. Int. J. Food Microbiol. 125:188-196.

Ercolini, D., F. Russo, G. Blaiotta, O. Pepe, G. Mauriello, and F. Villani. 2007. Simultaneous detection of Pseudomonas fragi, P. lundensis, and $P$. putida from meat by use of a multiplex PCR assay targeting the carA gene. Appl. Environ. Microbiol. 73:2354-2359.

Ercolini, D., F. Russo, I. Ferrocino, and F. Villani. 2009. Molecular identification of mesophilic and psychrotrophic bacteria from raw cow's milk. Food Microbiol. 26:228-231. 
Glück, C., E. Rentschler, M. Krewinkel, M. Merz, M. von Neubeck, M. Wenning, S. Scherer, M. Stoeckel, J. Hinrichs, T. Stressler, and L. Fischer. 2016. Thermostability of peptidases secreted by microorganisms associated with raw milk. Int. Dairy J. 56:186-197.

Guo, X., R. Long, M. Kreuzer, L. Ding, Z. Shang, Y. Zhang, Y. Yang, and G. Cui. 2014. Importance of functional ingredients in yak milk-derived food on health of Tibetan nomads living under highaltitude stress: A review. Crit. Rev. Food Sci. Nutr. 54:292-302.

Kumar, D., A. K. Verma, M. K. Chatli, R. Singh, P. Kumar, N. Mehta, and O. P. Malav. 2016. Camel milk: Alternative milk for human consumption and its health benefits. Nutr. Food Sci. 46:217-227.

Li, L., J. A. Renye Jr., L. Feng, Q. Zeng, Y. Tang, L. Huang, D. Ren, and P. Yang. 2016. Characterization of the indigenous microflora in raw and pasteurized buffalo milk during storage at refrigeration temperature by high-throughput sequencing. J. Dairy Sci. 99:7016-7024.

Marchand, S., K. Coudijzer, M. Heyndrickx, K. Dewettinck, and J. De Block. 2008. Selective determination of the heat-resistant proteolytic activity of bacterial origin in raw milk. Int. Dairy J. 18:514-519.

Marchand, S., B. Duquenne, M. Heyndrickx, K. Coudijzer, and J. De Block. 2017. Destabilization and off-flavors generated by Pseudomonas proteases during or after UHT-processing of milk. Int. J. Food Contam. 4:2. https://doi.org/10.1186/s40550-016-0047-1.

Marchand, S., K. Heylen, W. Messens, K. Coudijzer, P. De Vos, K. Dewettinck, L. Herman, J. De Block, and M. Heyndrickx. 2009. Seasonal influence on heat-resistant proteolytic capacity of Pseudomonas lundensis and Pseudomonas fragi, predominant milk spoilers isolated from Belgian raw milk samples. Environ. Microbiol. 11:467-482.

Munsch-Alatossava, P., and T. Alatossava. 2006. Phenotypic characterization of raw milk-associated psychrotrophic bacteria. Microbiol. Res. 161:334-346.

Nicodème, M., J. P. Grill, G. Humbert, and J. L. Gaillard. 2005. Extracellular protease activity of different Pseudomonas strains: Dependence of proteolytic activity on culture conditions. J. Appl. Microbiol. 99:641-648.

Polychroniadou, A. 1988. A simple procedure using trinitrobenzenesulphonic acid for monitoring proteolysis in cheese. J. Dairy Res. 55:585-596.

Quigley, L., O. O'Sullivan, C. Stanton, T. P. Beresford, R. P. Ross, G. F. Fitzgerald, and P. D. Cotter. 2013. The complex microbiota of raw milk. FEMS Microbiol. Rev. 37:664-698.

Rajmohan, S., C. E. Dodd, and W. M. Waites. 2002. Enzymes from isolates of Pseudomonas fluorescens involved in food spoilage. J. Appl. Microbiol. 93:205-213.

Sajben, E., L. Manczinger, A. Nagy, L. Kredics, and C. Vagvolgyi. 2011. Characterization of pseudomonads isolated from decaying sporocarps of oyster mushroom. Microbiol. Res. 166:255-267.
Scarpellini, M., L. Franzetti, and A. Galli. 2004. Development of PCR assay to identify Pseudomonas fluorescens and its biotype. FEMS Microbiol. Lett. 236:257-260.

Scatamburlo, T. M., A. K. Yamazi, V. Q. Cavicchioli, F. A. Pieri, and L. A. Nero. 2015. Spoilage potential of Pseudomonas species isolated from goat milk. J. Dairy Sci. 98:759-764.

Spilker, T., T. Coenye, P. Vandamme, and J. J. LiPuma. 2004. PCRbased assay for differentiation of Pseudomonas aeruginosa from other Pseudomonas species recovered from cystic fibrosis patients. J. Clin. Microbiol. 42:2074-2079.

The Guangxi Zhuang Autonomous Region Health and Family Planning Commission. 2014. Guangxi Zhuang Autonomous Region Local Standard, Raw Buffalo Milk. The Guangxi Zhuang Autonomous Region Health and Family Planning Commission, Guangxi Zhuang Autonomous Region, China.

Watanabe, K., J. Fujimoto, M. Sasamoto, J. Dugersuren, T. Tumursuh, and S. Demberel. 2008. Diversity of lactic acid bacteria and yeasts in Airag and Tarag, traditional fermented milk products of Mongolia. World J. Microbiol. Biotechnol. 24:1313-1325.

Wiedmann, M. D. Weilmeier, S. S. Dineen, R. Ralyea, and K. J. Boor. 2000. Molecular and phenotypic characterization of Pseudomonas spp. isolated from milk. Appl. Environ. Microbiol. 66:2085-2095.

Willocx, F., M. Mercier, M. Hendrickx, and P. Tobback. 1993. Modelling the influence of temperature and carbon dioxide upon the growth of Pseudomonas fluorescens. Food Microbiol. 10:159-173.

Xin, L., Z. X. Meng, L. W. Zhang, Y. H. Cui, X. Han, and H. X. Yi. 2017. The diversity and proteolytic properties of psychrotrophic bacteria in raw cows' milk from North China. Int. Dairy J. 66:34-41.

Yu, J., W. H. Wang, B. L. Menghe, M. T. Jiri, H. M. Wang, W. J. Liu, Q. H. Bao, Q. Lu, J. C. Zhang, F. Wang, H. Y. Xu, T. S. Sun, and H. P. Zhang. 2011. Diversity of lactic acid bacteria associated with traditional fermented dairy products in Mongolia. J. Dairy Sci. 94:3229-3241.

Zahran, A. S., and A. A. Al-Saleh. 1997. Isolation and identification of protease-producing psychrotrophic bacteria from raw camel milk. Aust. J. Dairy Technol. 52:5-7.

Zhang, H. P., J. Xu, J. G. Wang, Menghebilige, T. S. Sun, H. P. Li, and M. R. Guo. 2008. A survey on chemical and microbiological composition of kurut, naturally fermented yak milk from Qinghai in China. Food Contr. 19:578-586.

Zhang, W. W., Y. H. Hu, H. L. Wang, and L. Sun. 2009. Identification and characterization of a virulence-associated protease from a pathogenic Pseudomonas fluorescens strain. Vet. Microbiol. 139:183-188. 